
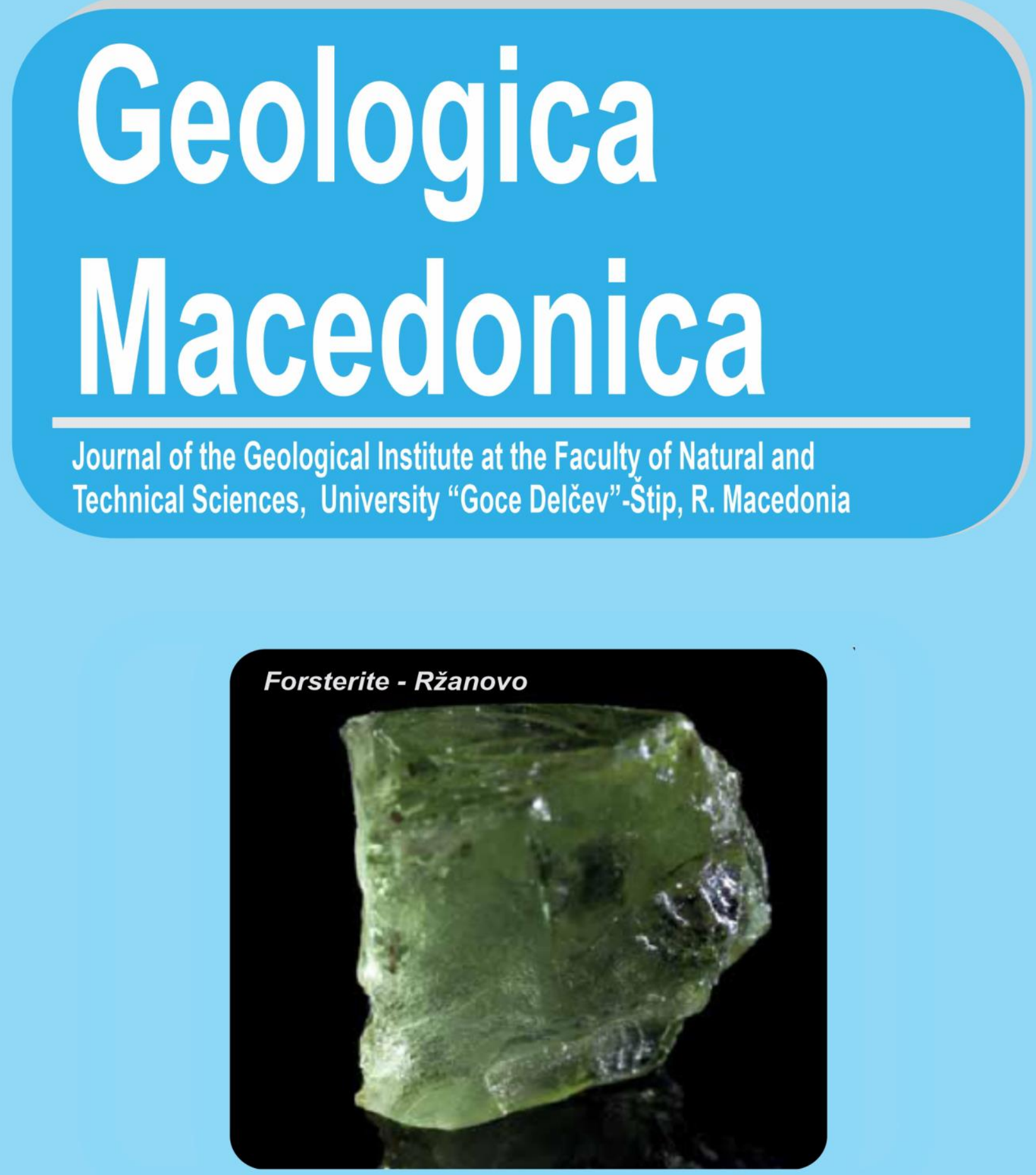

\begin{tabular}{|c|c|c|c|c|}
\hline $\begin{array}{l}\text { Geologica Macedonica } \\
\text { Geologica Macedonica }\end{array}$ & $\begin{array}{ll}\text { Vol. } & \mathbf{3 5} \\
\text { Год. } & \end{array}$ & $\begin{array}{l}\text { No } \\
\text { Број }\end{array}$ & $\begin{array}{l}\text { pp. } \\
\text { стр. }\end{array}$ & \begin{tabular}{|l} 
Štip \\
Штип
\end{tabular} \\
\hline
\end{tabular}




\section{GEOLOGICA MACEDONICA}

\begin{tabular}{|c|c|c|c|c|}
\hline $\begin{array}{l}\text { Geologica Macedonica } \\
\text { Geologica Macedonica }\end{array}$ & $\begin{array}{ll}\text { Vol. } & \mathbf{3 5} \\
\text { Год. } & \mathbf{3 5} \\
\end{array}$ & $\begin{array}{ll}\text { No } & \\
\text { Бpoj } & \\
\end{array}$ & $\begin{array}{ll}\text { pp. } & \text { 69-152 } \\
\text { стр. }\end{array}$ & \begin{tabular}{|l} 
Štip \\
Штип
\end{tabular} \\
\hline
\end{tabular}




\begin{tabular}{|c|c|c|c|c|}
\hline $\begin{array}{l}\text { Geologica Macedonica } \\
\text { Geologica Macedonica }\end{array}$ & $\begin{array}{l}\text { Vol. } \\
\text { Год. } \mathbf{3 5}\end{array}$ & $\begin{array}{l}\text { No } \\
\text { Број } 2\end{array}$ & $\begin{array}{l}\text { pp. } \\
\text { стр. }\end{array}$ & $\begin{array}{l}\text { Štip } \\
\text { Штип }\end{array}$ \\
\hline
\end{tabular}

\section{GEOLOGICA MACEDONICA}

Published by: - Издава:

"Goce Delčev" University in Štip, Faculty of Natural and Technical Sciences, Štip, North Macedonia Универзитет „Гоце Делчев“ во Штип, Факултет за природни и технички науки, Штип, Северна Македонија

\section{EDITORIAL BOARD}

Todor Serafimovski (N. Macedonia), Editor in Chief, Blažo Boev (N. Macedonia), Editor,

David Alderton (UK), Tadej Dolenec (Slovenia), Ivan Zagorchev (Bulgaria), Wolfgang Todt (Germany), Nikolay S. Bortnikov (Russia), Clark Burchfiel (USA), Thierry Augé (France), Todor Delipetrov (N. Macedonia), Vlado Bermanec (Croatia), Milorad Jovanovski (N. Macedonia), Spomenko Mihajlović (Serbia), Dragan Milovanović

(Serbia), Dejan Prelević (Germany), Albrecht von Quadt (Switzerland), Sabina Strmić-Palinkaš (Norway).

\section{УРЕДУВАЧКИ ОДБОР}

Тодор Серафимовски (С. Македонија, главен уредник), Блажо Боев (С. Македонија, уредник), Дејвид Олдертон (В. Британија), Тадеј Доленец (Словенија), Иван Загорчев (Бугарија), Волфганг Тод

(Германија), Николај С. Бортников (Русија), Кларк Барчфил (САД), Тиери Оже (Франција),

Тодор Делипетров (С. Македонија), Владо Берманец (Хрватска), Милорад Јовановски (С. Македонија),

Споменко Михајловиќ (Србија), Драган Миловановиќ (Србија), Дејан Прелевиќ (Германија), Албрехт фон Квад (Швајцарија), Сабина Стрмиќ-Палинкаш (Норвешка)

Language editor Лектура

Proof-Reading-Serice.com, Ltd, Devonshire

Business Centre, Works Road, Letchworth Garden City, Hertfordshire, SG6 1GJ, United Kingdom

(English) (англиски)

Technical editor Технички уредник

Blagoja Bogatinoski Благоја Богатиноски

Proof-reader Коректор

Alena Georgievska Алена Георгиевска

Address Адреса

GEOLOGICA MACEDONICA GEOLOGICA MACEDONICA

EDITORIAL BOARD PEДAКЦИJA

Faculty of Natural and Technical Sciences

Факултет за природни и технички науки

P. O. Box 96

пошт. фах 96

MK-2000 Štip, North Macedonia МК-2000 Штип, Северна Македонија

Tel. ++ 389032550575 Тел. 032550575

E-mail: todor.serafimovski@ugd.edu.mk

$\begin{aligned} 400 \text { copies } & \text { Тираж: } 400 \\ \text { Published twice yearly } & \text { Излегува два пати годишно } \\ \text { Printed by: } & \text { Печати: } \\ 2^{\text {ri }} \text { Avgust - Štip } & 2^{\text {ри } А в г у с т ~-~ Ш т и п ~} \\ \text { Price: } 10 € & \text { Цена: } 500 \text { ден. } \\ \text { Брhed in December 2021 } & \text { Бројот е отпечатен во декември } 2021\end{aligned}$

The edition is published in December 2021

Бројот е отпечатен во декември 2021 


\begin{tabular}{|c|c|c|c|c|}
\hline $\begin{array}{l}\text { Geologica Macedonica } \\
\text { Geologica Macedonica }\end{array}$ & $\begin{array}{ll}\text { Vol. } & \mathbf{3 5} \\
\text { Год. } & \end{array}$ & $\begin{array}{l}\text { No } \\
\text { Број }\end{array}$ & $\begin{array}{l}\text { pp. } \\
\text { стр. }\end{array}$ & $\begin{array}{l}\text { Štip } \\
\text { Штип }\end{array}$ \\
\hline
\end{tabular}

\section{TABLE OF CONTENTS}

374. Filip Arnaut, Branislav Sretenović

SOME EXAMPLES OF ELECTRICAL IMAGING (ERT) AND GROUND

PENETRATING RADAR (GPR) IN SOLVING CIVIL ENGINEERING PROBLEMS

375. Boško Boškovski, Simeon Jančev, Blagoj Pavlovski, Arianit A. Reka, Andrijana Čankuloska,Slobodan Bogoevski

CHARACTERIZATION OF THE CALCITE RAW MATERIAL

FROM THE MICROLOCALITIES OF SUŠIČKI MOST AND GORNA BANJICA

NEAR GOSTIVAR, REPUBLIC OF NORTH MACEDONIA

376. Darko Bačvarovski, Robert Šajn, Trajče Stafilov

DISTRIBUTION OF CHEMICAL ELEMENTS IN SEDIMENTS

AND ALLUVIUM SOILS FROM THE PČINJA RIVER BASIN,

NORTH MACEDONIA.

$95-113$

377. Todor Serafimovski, Blažo Boev, Goran Tasev, Ivan Boev, Dalibor Serafimovski

MINERALOGICAL ANALYSIS OF SAMPLES FROM THE BUČIM TAILING

DAM DRILL HOLES

378 Darko, Pižov, Vojo Mirčovski, Gjorgji Dimov

VULNERABILITY ASSESSMENT OF POLLUTION OF GROUNDWATER

IN THE ŠTIP AQUIFER WITH APPLICATION OF GOD METHOD

$131-139$

379 Kim Mezga, Matej Dolenec, Dejan Šram, Petra Vrhovnik

POTENTIALLY TOXIC ELEMENTS IN THE DRAVINJA RIVER SEDIMENTS

(EASTERN SLOVENIA)

$141-150$

Instructions to authors $.151-152$ 


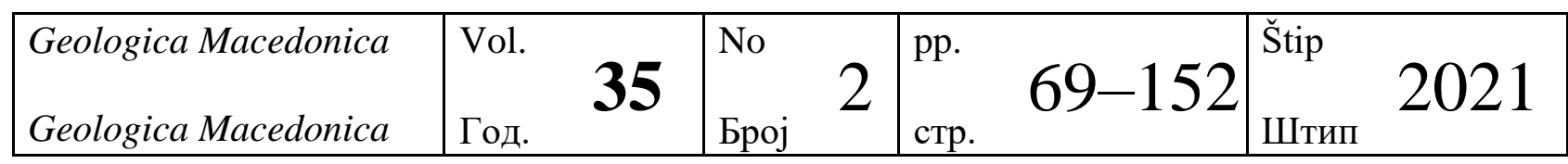

\section{СОДРЖИНА}

374 Филип Арнаут, Бранислав Сретеновиќ

НЕКОИ ПРИМЕРИ НА ПРИМЕНАТА НА МЕТОДОТ НА ЕЛЕКТРИЧНО

СКЕНИРАЬЕ (ЕРТ) И ГЕОРАДАР (ГПР) ВО РЕШАВАҢЕ ПРОБЛЕМИ

ОД ГРАДЕЖНОТО ИНЖЕНЕРСТВО

375 Бошко Бошковски, Симеон Јанчев, Благој Павловски, Арианит А. Река,

Александра Чанкулоска, Слободан Богоевски

КАРАКТЕРИЗАЦИЈА НА КАЛЦИТНИ СУРОВИНИ ОД МИКРОЛОКАЛИТЕТИТЕ

СУШИЧКИ МОСТ И ГОРНА БАЮИЦА БЛИЗУ ГОСТИВАР,

СЕВЕРНА МАКЕДОНИЈА

376 Дарко Бачваровски, Роберт Шајн, Трајче Стафилов ДИСТРИБУЦИЈА НА ХЕМИСКИ ЕЛЕМЕНТИ ВО СЕДИМЕНТИТЕ И АЛУВИЈАЛНИТЕ ПОЧВИ ОД СЛИВОТ НА РЕКАТА ПЧИЬА, СЕВЕРНА МАКЕДОНИЈА

377 Тодор Серафимовски, Блажо Боев, Горан Тасев, Иван Боев, Далибор Серафимовски МИНЕРАЛОШКА АНАЛИЗА НА ПРИМЕРОЦИ ОД ДУПЧЕТИНИ ВО ХИДРОЈАЛОВИШТЕТО НА БУЧИМ.

378. Дарко Пижов, Војо Мирчовски, Ѓорѓи Димов

ОЦЕНА НА РАНЛИВОСТА НА ПОДЗЕМНИТЕ ВОДИ ОД ЗАГАДУВАњЕ

ВО ШТИПСКИОТ ВОДОНОСНИК СО ПРИМЕНА НА GOD-МЕТОДОТ $131-139$

379. Ким Мезга, Матеј Доленец, Дејан Шрам, Петра Врховник ПОТЕНЦИЈАЛНО ТОКСИЧНИ ЕЛЕМЕНТИ ВО СЕДИМЕНТИТЕ НА РЕКАТА ДРАВИњА (ИСТОЧНА СЛОВЕНИЈА). $141-150$ 
Geologica Macedonica, Vol. 35, No. 2, pp. 115-129 (2021)

On print ISSN $0352-1206$

On line ISSN $1857-8586$

UDC: $622.34 ' 17: 550.42 .08(497.741)$

https://doi.org/10.46763/GEOL21352115s

Original scientific paper

\title{
MINERALOGICAL ANALYSIS OF SAMPLES FROM THE BUČIM TAILING DAM DRILL HOLES
}

\author{
Todor Serafimovski ${ }^{1}$, Blažo Boev ${ }^{1}$, Goran Tasev ${ }^{1}$, Ivan Boev ${ }^{1}$, Dalibor Serafimovski ${ }^{2}$ \\ ${ }^{1}$ Faculty of Natural and Technical Sciences, Institute of Geology, “Goce Delčev" University in Štip, \\ Blvd. Goce Delčev 89, 2000 Štip, Republic of North Macedonia \\ ${ }^{2}$ Faculty of Electrical Engineering, "Goce Delčev" University in Štip, \\ Blvd. Goce Delčev 89, 2000 Štip, Republic of North Macedonia \\ todor.serafimovski@ugd.edu.mk
}

\begin{abstract}
A b s tra c t: The tailing dam in the Bučim mine is an important segment in the exploitation of porphyry ores from the Bučim mine and in the period of 40 years there has been deposited over $135 \mathrm{Mt}$ of tailings which contains interesting contents of gold, copper, silver and other rare and dispersed elements, which at the makes the tailing dam technogenic deposit. In the framework of this paper, the mineralogical aspect of the tailings was treated on the basis of samples taken from 6 boreholes and studied 30 ore-microscopic polished sections. The detailed microscopic study confirmed the expected mineral association represented by Fe-oxides, mainly magnetite and maghemite, then chalcopyrite, natural gold, pyrite, sulfosols and others. Scanning electron microscope study confirmed the established mineral association and gave the compositions of the major ore minerals. During the analysis and comparison with the standards for these types of mineral species, it was concluded that these are the leading minerals primarily chalcopyrite and natural gold that show a high degree of purity, where the variations of copper range from 32.43 to $34.53 \% \mathrm{Cu}$ in chalcopyrite and from 98.73 to $98.79 \%$ Au in native gold, where small variations especially in native gold are due to the presence of $\mathrm{Ag}, \mathrm{Cu}$ and $\mathrm{Te}$. Similar relationships have been found in other mineral species examined under the scanning electron microscope, which can be seen from the data presented in the paper.
\end{abstract}

Key words: Bučim copper mine; tailing; ore microscopy; mineral association; samples

\section{INTRODUCTION}

In the future, the tailing dam Topolnica should be an interesting technogene deposit, primarily due to the increased presence of $\mathrm{Cu}$ and $\mathrm{Au}$ in it. Therefore, in the forthcoming period, great attention will be paid to the study of these types of sites and the modern methods of their exploitation. The general characteristic of the tailing dams as technogene deposits is that the material after flotation of the processed ore treated as slag is transported and deposited on a predetermined space. Flotation slag is taken as an aqueous solution (pulp) with finely ground particles of ore and waste minerals (Lottermoser, 2007).

The size of the tailing depends primarily on the amount of material coming from the flotation (which should be known), and the shape of the same depends on the configuration of the selected deposition area for it. The tailing slag flow, in the form of a pulp, has a different concentration of useful components (depending on the input ore and their utilization during the flotation), and therefore the useful components often form layers (Pavičević et al., 1982; Tudjarov et al., 1996; Čifliganec et al, 1997).

As with other mineral resource deposits, the ultimate goal of the study is to determine the reserves, the average content of the useful component, the nature of the occurrence and their distribution (Tudjarov et al., 1996). The basic method of exploring these deposits is exploration drilling in order to pass through the tailing and reach the bedrock, or its base. From the above it follows that the drill-holes are relatively shallow. The greatest variability of concentrations of the components should be expected in the direction of the tailing flow, which is above all the shorter axis of the tailing dam 
(isometric forms of the tailing dams are rare because the shape of valleys on which the dams were previously built). The density of the exploration drillholes network depends on the size of the deposit and the nature of the variability of the useful components in the deposit. The distance between the exploration cross-sections is usually $50-100 \mathrm{~m}$, while between the exploration drill-holes along the crosssection is $20-40 \mathrm{~m}$, and less frequently $10 \mathrm{~m}$. Such networks can be placed in old dried tailing dam parts. In the wetlands that are in formation, or are recently formed and there is still water in them, the exploration drill-holes will be placed in the places where the drilling rig is possible to work because of the unbound material it sinks into the tailing. Therefore, exploration drill-holes are installed only in the accessible parts of the tailing dam, which reduces the representativeness of the collected data. The layout and the distance of the individual exploration drill-holes is determined separately for each tailing dam (Tudjarov et al., 1996). An integral part of the exploration is the study of the material from the drill-holes taken at $1 \mathrm{~m}$ in length from the drill-hole. Geochemical mapping methods should investigate the material composition of the tailing, to estimate the reserves of the metal in general and the individual layers or parts. By computer processing, a map of the allocation of reserves in the individual parts should be prepared. The state of ecological pollution of the environment should also be assessed and the most effective measures for the preservation of the environment should be proposed (Tudjarov et al., 1996; Lottermoser, 2007).

It is known that during the exploitation and processing of the ore in the flotation, no complete extraction of the useful components is carried out, while some of them are completely disposed of in the tailing. Complete extraction is not done due to several reasons: at the moment of processing there was no appropriate technological procedure, low content that at the time of exploitation does not allow for cost-effective use, partial use of the component, etc.

\section{MATERIALS AND METHODS}

Within the current ore minerals study of the Bučim mine tailing waste dam material, were analyzed 30 samples (that have proven as the most promising) taken from cores of 6 exploration drill holes (B1, B2, B3, B4, B5 and B6). From the samples were prepared 30 polished sections that were previewed in the microscopic laboratories of the Faculty of Natural and Technical Sciences in Štip, Department of Mineral Deposits on Polarizing Microscope type ZEISS Axiolab DX (with Integraed camera Datasim MC 80 D4) and the LEICA DMP 4500 microscope equipped with a digital camera and the appropriate LEICA LAS software. In-depth microscopy combinations of lenses with magnifications of $10 \times, 20 \times, 40 \times, 50 \times$ and $63 \times$ were used, in combination with eyepieces of $10 \times$ magnification. This practically means that we had a wide observation range of $100 \times$ to $630 \times$ magnification, which allowed us to directly observe details below $50 \mu \mathrm{m}$.

The most interesting mineral assemblages were subjected to further study. Namely, the chemical compositions of the major mineral phases were determined by scanning electron microscope (SEM). The SEM analyses were recorded on the scanning electron microscopy VEGA3 LMU and INCA Energy 250 Microanalysis System, located at the "Goce Delčev" University in Štip, for quantitative analyses of the samples. The SEM analyses were performed with the SE (Scattered Electrons) detector on $20 \mathrm{kV}$ voltage. First, the samples were cleaned and then a small piece was put on the sample holder with carbon double adhesive tape on it. The sample's surface was coated with gold on Modular Coater, Quorum Q150R ES and then analyzed in high vacuum mode with more than 0.018 $\mathrm{Pa}$. The sample surface was motorized on 5 axes (x$y-z$, rotation and tilt). For SEM, the Vega TC software was used. The energy dispersive X-ray (EDX) system for SEM is a fully quantitative SDD with excellent performance at low and high count rates, which is capable of achieving a resolution better than $125 \mathrm{eV}$ on the $\mathrm{MnK} \alpha, \mathrm{FK} \alpha$ and $\mathrm{CK} \alpha$ peaks. The working distance for X-ray was $15 \mathrm{~mm}$. The detector control and data acquisition were done with INCA software. The SEM-EDS analyses were done on the unpolished surfaces.

The quantitive mineralogy of the samples was determined by X-ray diffractometry XRD. A Philips PW3710 X-ray diffractometer was used with $\mathrm{Cu}-\mathrm{K} \alpha$ $1.54060 \AA$ radiation generated at $40 \mathrm{kV}$ and $30 \mathrm{~mA}$. The sample was scanned at a rate of $1.2^{\circ}$ per minute, over the range of $2-70^{\circ}(2 \theta)$. The diffraction pattern were identified and quantified using X'Pert High Score Plus 4.8 software and the data from the PANICSD database, version 2.3. 


\section{GENERAL FEATURES OF THE BUČIM TAILING DAM}

The produced copper ore from the Bučim mine, with an average annual production of 4,000,000 tons, has been processed in the flotation facility, where during the processing of copper minerals was produced tailing of about 3,950,000 t, which is safely discharged and deposited within the tailing dam (Figure 1).

The location of the tailing reservoir is east of the flotation plant, about $2.2 \mathrm{~km}$ (up to the tailing dam). The tailing dam of the Bučim mine is built in the river flow of the Topolnica river, with the direction east-west, and connects the hills of Tashli Bair (629 m.) on the west and Kartal (800 m.) on the east.

The accumulation profile is located about 500 $\mathrm{m}$ upstream from the village of Topolnica. The accumulation extends upstream to the mouth of the stream that drains from the village of Počivalo at a length of about $1000 \mathrm{~m}$. The accumulation space on both sides is limited by the mountain ranges of Plačkovica Mountain. The place where the dam core is built is located in the amphibolite schist and gneiss that on the surface have decomposed and stripped off. The width of the cross section at the height of the slope level is $265 \mathrm{~m}$. Overall, the cross section is symmetrical. The left side has a slope of about $30^{\circ}$ and is steeper with respect to the right whose slope is about $20^{\circ}$. Before the construction of the dam core, detailed study of the geophysical, geomechanical, geochemical, seismic and hydrogeological characteristics of the wider terrain were carried out.

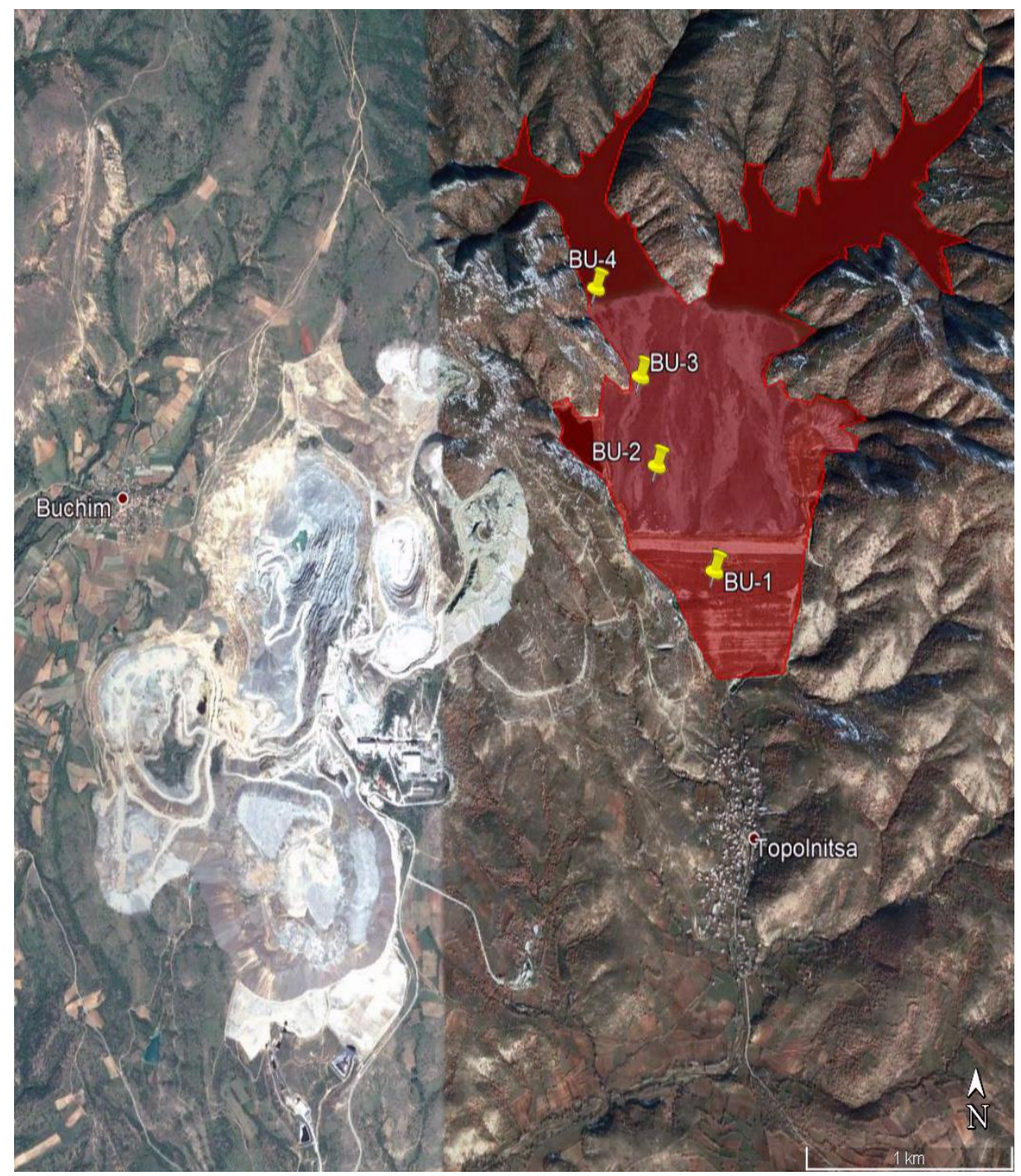

Fig. 1. The location of the Bučim mine tailing dam, Republic of North Macedonia 
From the data related to the tailing dam of the Bučim mine, it can be concluded that it represents a significant infrastructure object within the Bučim mine and one of the basic capital facilities for the normal exploitation of porphyry $\mathrm{Cu}$-ores from the Bučim mine. Bearing in mind that most of the mined ore (> 97\%) which in the last years exceeds the figure of $4200000 \mathrm{t}$ annually, ends up in the form of a fluid floating pulp (tailing) on the tailing dam, then it is very important to understand the meaning of this capital mine facility, which, as we have said, has multiple meanings. In addition, it is our duty to emphasize the constant concern of the company in terms of oscillation and the overall safety and security of the tailing dam, parallel care is also taken to meet the environmental standards in and around the tailing dam and its immediate surroundings.

According to all up to date carried out projects for the overhang of the existing tailing dam Topolnica, as well as the annual elaborates for the osculation of the crown of the Bučim tailing dam, the current level of the dam is $654 \mathrm{~m}$, and as of 2018, in the tailing dam Bučim is deposited tailing material in amount of 135,414,895 $\mathrm{t}$ (Figure 2).

From Figure 2, can be seen that the Bučim mine is active for 40 years, starting in 1979. It constantly produced mined waste that went to the waste dump and tailing material that was deposited at the tailing dam. Discontinuity only occurred in 2004 when the mine was in a halt due to a change in the ownership structure. From 2005 to the present, the continuity has been maintained with increased quantities of ore production, which is slightly over 4 million tons, and continuous production of tailing, which was deposited in the tailing dam Bučim, with quantities that are also slightly more than 4 million tons annually. Bučim is in operation in 2019. The plot below shows the classical exponential trend in the quantities of tailing material which was deposited at the tailing dam in the period from 1979 to 2018. Abstinence is clearly visible at the level of nearly 80 million tons of tailing, which detected the period from the end of 2003 and 2004. After that, we have a continuous growth until 2018, where the total mass of deposited tailing, as we already mentioned, is 135414895 tons.

The crown of the dam is stable and under constant observation by the technical services. Since the beginning of the 2021 within the Bučim tailing dam is deposited material, which is result of the Borov Dol ore flotation process.

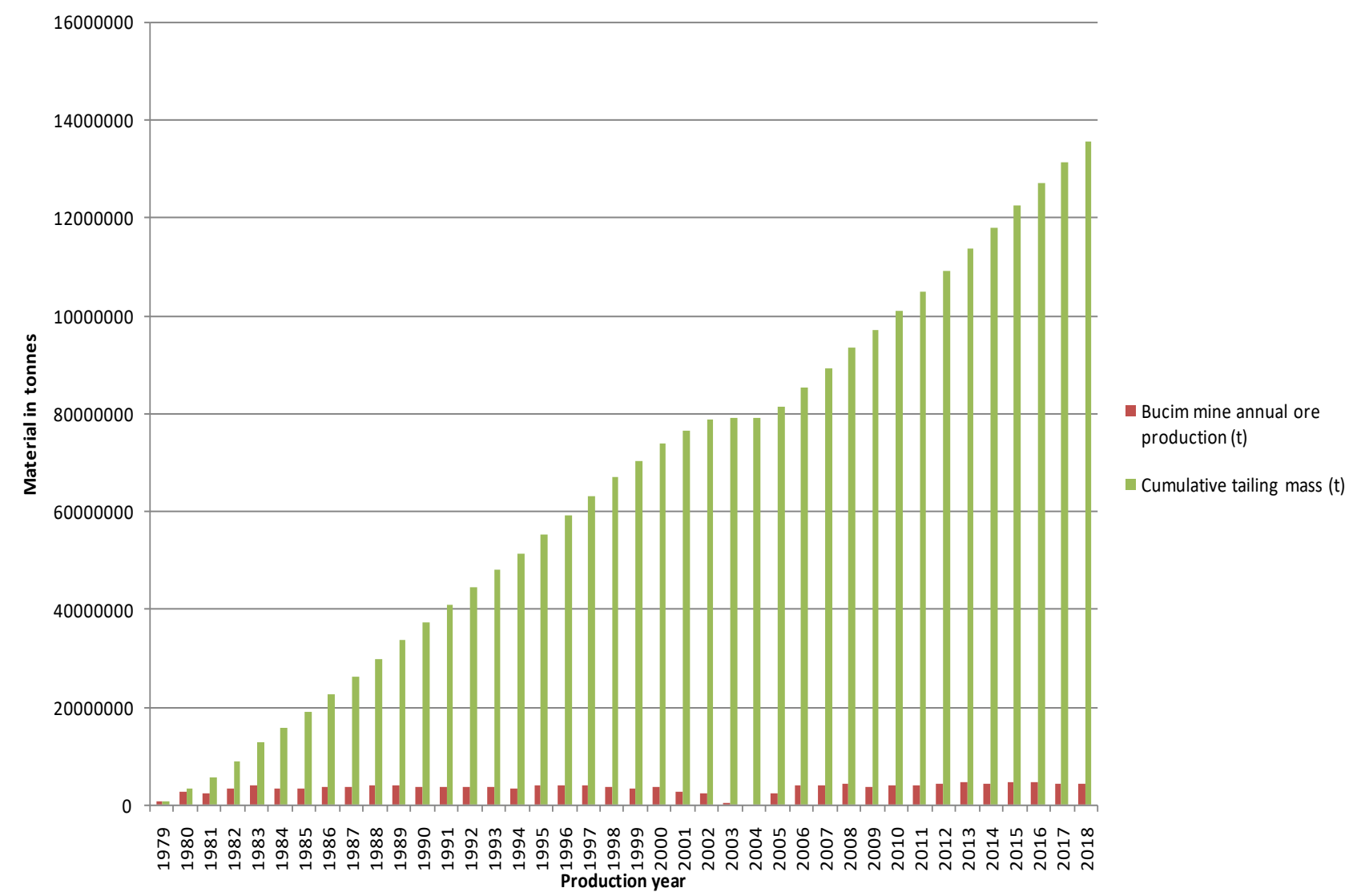

Fig. 2. Annual ore production and cumulative tailing mass within the Bučim mine tailing dam 


\section{ORE MICROSCOPY AND SCANNING ELECTRON MICROSCOPY RESULTS}

After the microscopic study of the polished sections, a total of 6 samples with details of ore grains were analyzed on the Scanning Electron Microscope in the laboratories of the Faculty of Natural and Technical Sciences at University "Goce Delčev" in Štip. The selection of the individual details that were dealt with for SEM analysis was based on the variety of ore minerals, their compactness, their representative morphological forms and, of course, their position which enables reliable diagnostics under SEM. Based on the above criteria, we selected globular pyrite and magnetite, relict chalcopyrite, standard magnetite, standard pyrite and chalcopyrite and individual grains of native gold. Analyses have shown that the analyzed ore minerals confirm the positive identification under the optical microscope and give the minerals compositions with some influence on the associated trace minerals standard for minerals of this type. The associated trace elements found in pyrite, chalcopyrite, magnetite and native gold are in direct correlation with the standard values offered by the SEM in the process of analysis. Depending on the detection limit of the applied SEM we allow for some error in the percentage representation of some trace elements, however, given the overall analysis and composition of the major elements in the studied minerals, one can rightly conclude that these errors are small and in no way affect the correct provision of the minerals tested. Such ratios can be seen in the attached material (microphotographs and tables with compositions of the studied minerals) separately for each studied mineral. At the same time, from the attached material can be sean the locations of the analysis carried out through the designated points/spectrums documented by a separate SEM microphotograph, while the obtained composition from the analysis are given in separate tables. Complete analysis of several pyrite, several chalcopyrite, magnetite and native gold have been performed on this principle, and the study results are given for each analyzed mineral separately.

Numerous magnetite mineral grains determined during our SEM study showed the following composition ranges: iron $66.71-70.52 \% \mathrm{Fe}$, and oxygen $25.17-29.94 \% \mathrm{O}$, as well as some admixtures of manganese $0.98-2.10 \% \mathrm{Mn}$, titanium 0.37 $1.10 \% \mathrm{Ti}$, vanadium $0.90-1.50 \% \mathrm{~V}$, chromium $0.80-1.1 \% \mathrm{Cr}$, and sporadically nickel $0.33-0.85 \%$ Ni (Tables 1, 3 and 4; Figures 3, 5 and 6). These values of the major elements in magnetite, in average, are slightly different (around a percent) than the reference values (Deer et al., 1962) and similar to findings to similar types of deposits and industrial facilities (Serafimovski et al., 2021a; 2021b).

Pyrite mineral compositions determined during our SEM study showed the following elemental concentration ranges: $51.94-54.28 \% \mathrm{~S}, 43.60$ $45.01 \% \mathrm{Fe}$, as well as with some admixtures of copper $0.45-1.1 \% \mathrm{Cu}$, silver $0.1-0.32 \% \mathrm{Ag}$, vanadium $0.11-0.5 \% \mathrm{~V}$, manganese $0.89-1.20 \% \mathrm{Mn}$, and nickel $0.12-0.27 \% \mathrm{Ni}$ (see Table 2 and Table 6 as well as Figure 4 and Figure 8). Comparison of obtained data with reference data (Palache et al., 1944; Okrusch and Matthes, 2005), in average has shown only part of percent discrepancies between the values. Admixtures present within the pyrite composition strongly reflect the adjacent rock and mineralization setting of the Bučim deposit (Serafimovski 1992; Serafimovski et al., 2020; 2021c).

Chalcopyrite is the most common and the most important ore mineral in regards to copper mineralization of this particular deposit. Within the analyzed mineral aggregates (Figures 3, 5. 6 and 9; Tables 3, 4 and 7) we have determined that we are dealing with monomineral chalcopyrite in the form of grains and grainy aggregates, mostly pure and compact, but its general feature is that the most often it is trapped in quartz grains, captured by subsequent silicification or captured in silicified amphibolites. In places, this captivity goes along with the magnetite grains, and in places the chalcopyrite is corrosively inserted into the magnetite, all of which are captured/enclosed by subsequent silicification. The most probably, their precipitation simultaneously started and the deposition of chalcopyrite continued after the deposition of magnetite. Such distinctive chalcopyrite-magnetite association very likely could indicate the vicinity of a porphyry-copper system (Robb, 2005; Ristović, 2020).

Chalcopyrite mineral compositions determined during our SEM study showed the following elemental concentration ranges: $33.44-36.12 \% \mathrm{~S}$, $28.71-30.91 \% \mathrm{Fe}$ and $32.43-34.53 \% \mathrm{Cu}$, as well as with some admixtures of manganese $0.45-0.9 \%$ $\mathrm{Mn}$, zinc $0.85-1.15 \% \mathrm{Zn}$, nickel $0.25-0.8 \% \mathrm{Ni}$, silver $0.15-0.25 \% \mathrm{Ag}$, and cobalt $0.18-0.50 \% \mathrm{Co}$ (see Tables 3, 4 and 7 as well as Figures 3. 5, 6 and 9). Comparison of obtained data with reference data 
(Palache et al., 1944; Okrusch and Matthes, 2005), in average, has shown only part of percent discrepancies between the values. Also, we would like to stress that the aforementioned elemental composi- tion of chalcopyrite minerals from the Bučim tailing strongly reflects the mineralization and adjacent rocks setting as well as certain industrial processes in regard of enrichment of ore.

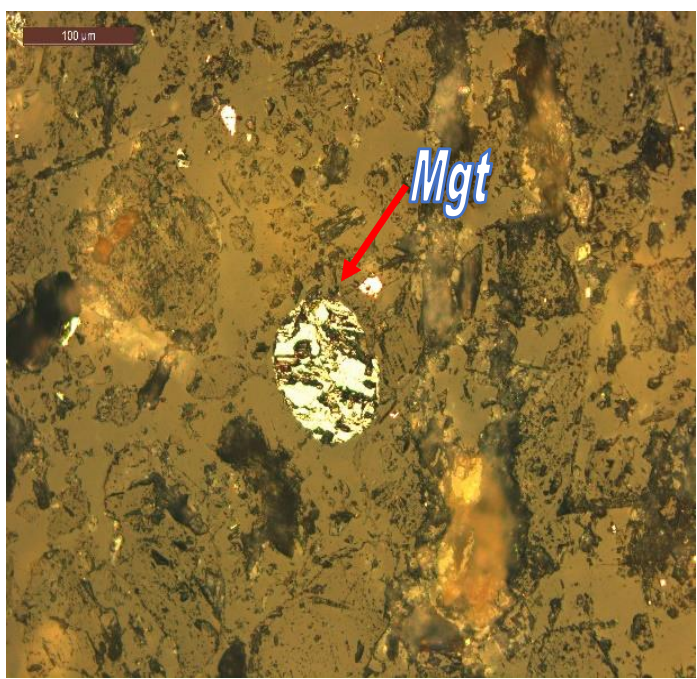

a)

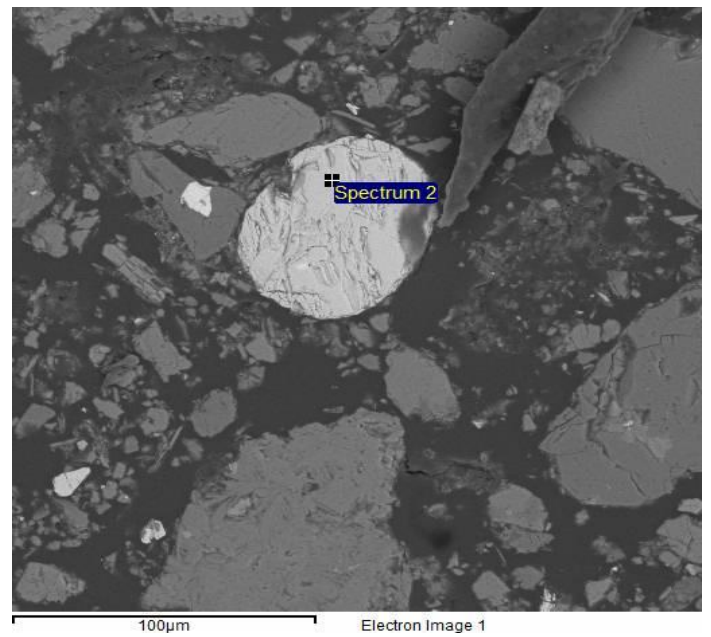

c)

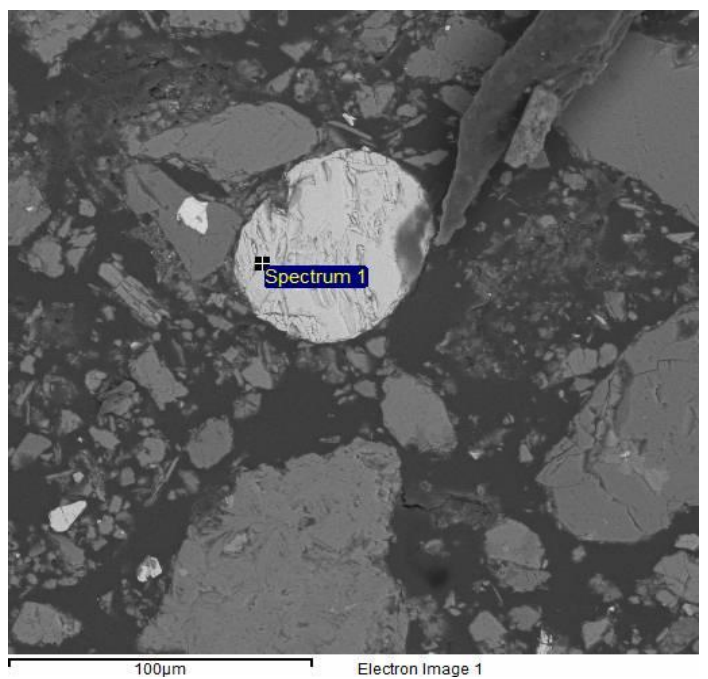

b)

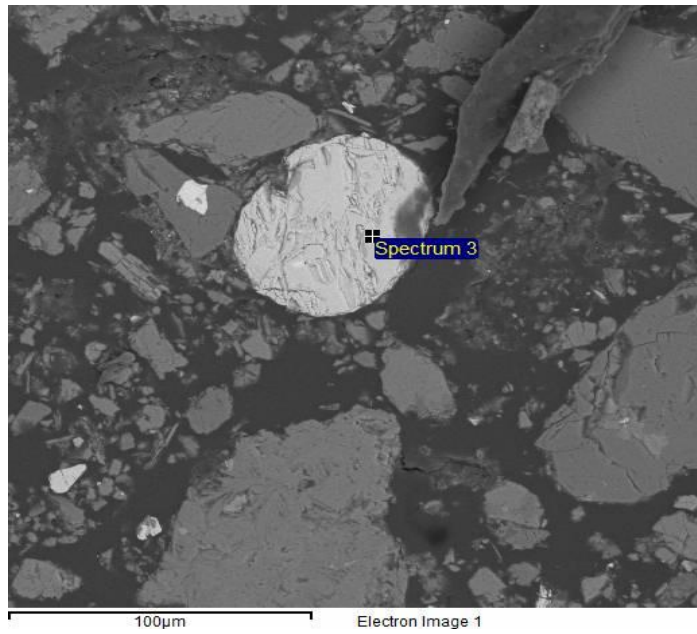

d)

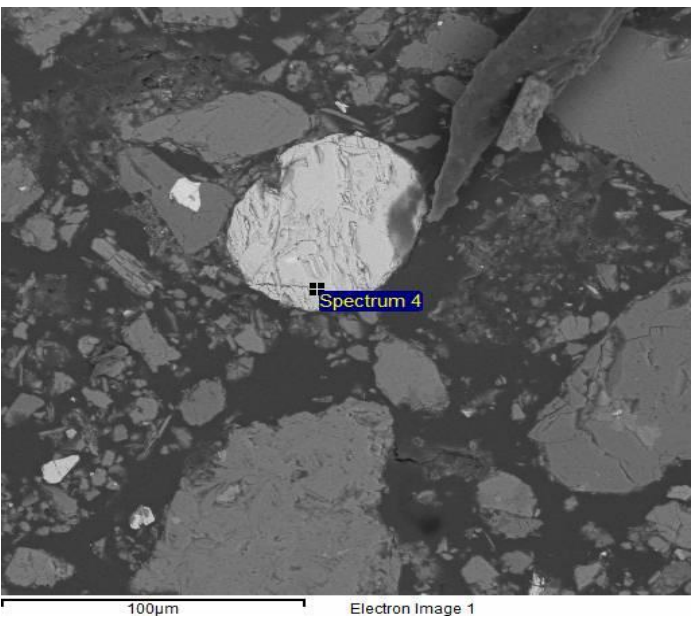

e)

Fig. 3. a) Single rounded magnetite grain partly corroded and with small chalcopyrite enclosures [magnif. $\times 200$, crossed nichols (polarized optical microscope)]; b-c-d-e) SEM analyses points 
Table 1

SEM analysis results of magnetite from the Bučim tailing dam (\%wt)

\begin{tabular}{|c|c|c|c|c|c|c|c|c|}
\hline \multirow{2}{*}{ Spectrum } & \multicolumn{7}{|c|}{$\begin{array}{lllllll} & 1 & \text { e } & m & \text { e } & n & t\end{array}$} & \multirow{2}{*}{ Total } \\
\hline & $\mathrm{Fe}$ & $\mathrm{O}$ & $\mathrm{Mn}$ & $\mathrm{Ti}$ & V & $\mathrm{Cr}$ & $\mathrm{Ni}$ & \\
\hline 1 & 69.92 & 25.77 & 1.76 & 0.37 & 0.90 & 0.95 & 0.33 & 100 \\
\hline 2 & 70.23 & 26.14 & 1.20 & 0.75 & 1.20 & - & 0.48 & 100 \\
\hline 3 & 69.89 & 25.17 & 1.10 & 0.50 & 1.50 & 0.99 & 0.85 & 100 \\
\hline 4 & 70.4 & 25.6 & 0.98 & 0.47 & 1.10 & 1.10 & 0.35 & 100 \\
\hline
\end{tabular}

Ta ble 2

SEM analysis results of pyrite from the Bučim tailing dam (\%wt)

\begin{tabular}{|c|c|c|c|c|c|c|c|c|}
\hline Spectrum & $S$ & $\mathrm{Fe}$ & $\begin{array}{c}\mathrm{E} \quad 1 \\
\mathrm{Cu}\end{array}$ & $\begin{array}{l}\mathrm{n} \quad \mathrm{e} \\
\mathrm{Ag}\end{array}$ & $\begin{array}{l}\mathrm{s} \\
\mathrm{V}\end{array}$ & $\mathrm{Mn}$ & $\mathrm{Ni}$ & Total \\
\hline 1 & 54.28 & 43.60 & 0.90 & 0.10 & 0.11 & 0.89 & 0.12 & 100 \\
\hline 2 & 53.92 & 43.67 & 0.73 & 0.19 & 0.23 & 1.13 & 0.13 & 100 \\
\hline 3 & 54.12 & 43.70 & 0.45 & 0.32 & 0.19 & 0.99 & 0.23 & 100 \\
\hline
\end{tabular}

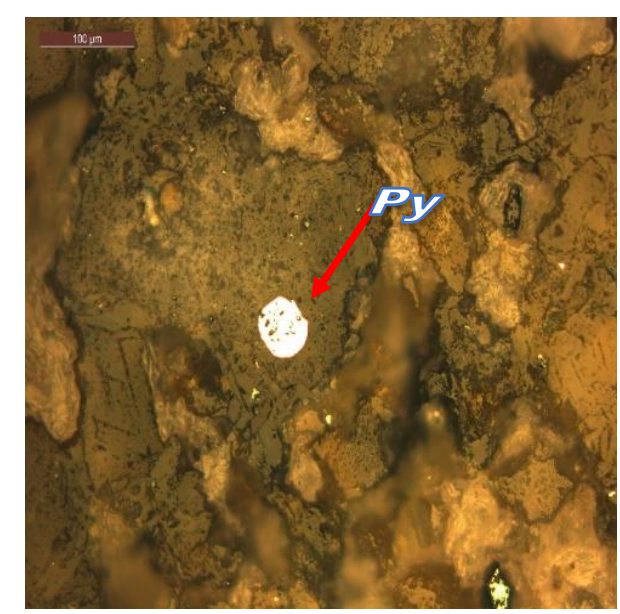

a)

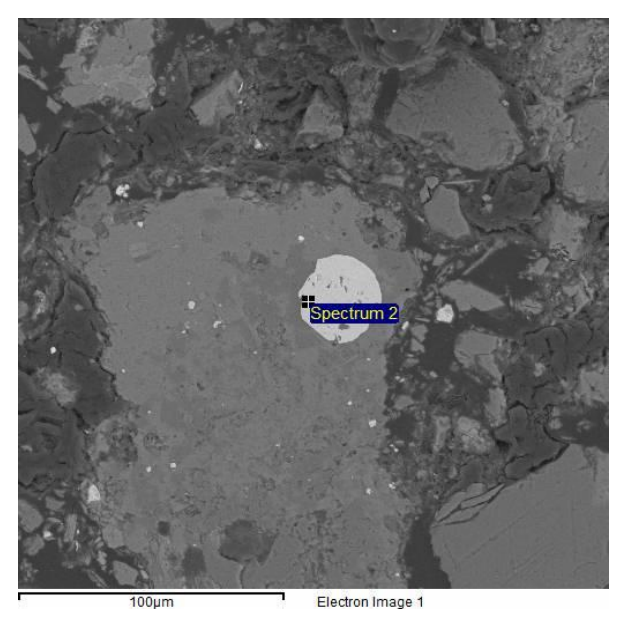

c)

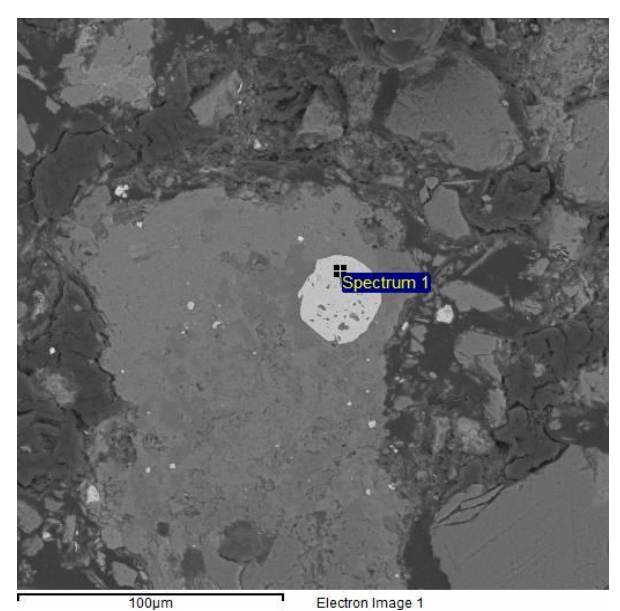

b)

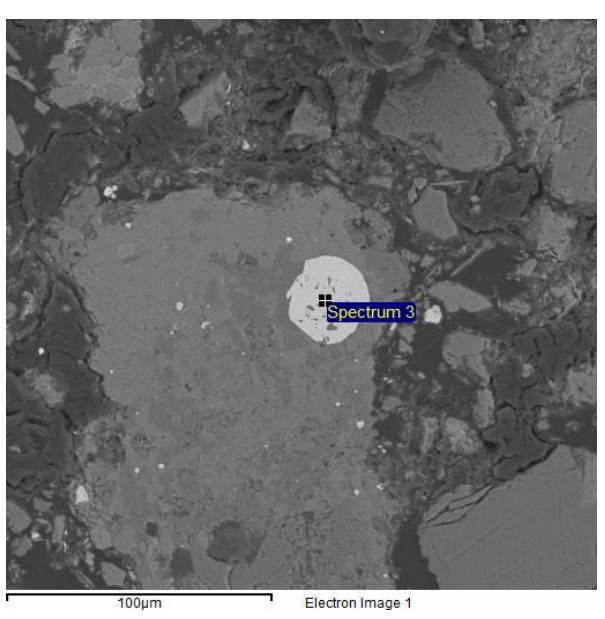

d)

Fig. 4. Single idiomorphic to hipidiomorphic massive pyrite grain (magnif. $\times 200$ ), a) crossed nichols (polarized optical microscope); b-c-d) SEM analyses points 


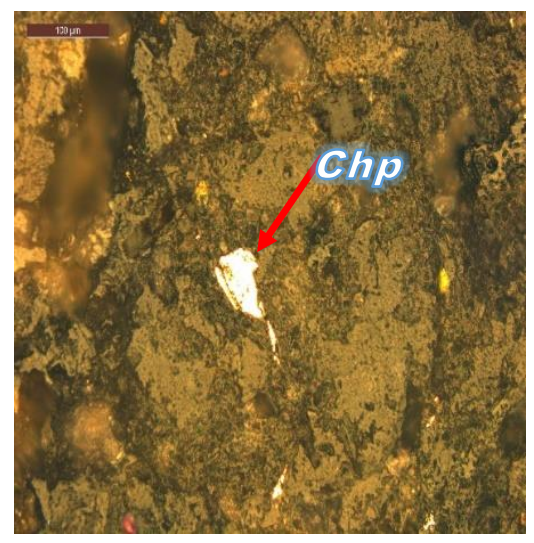

a)

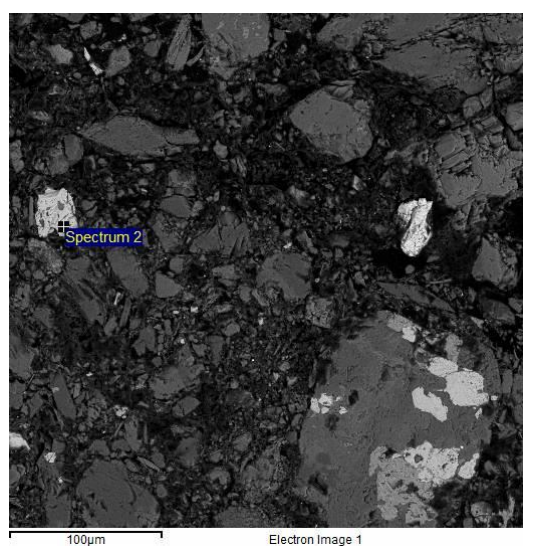

c)

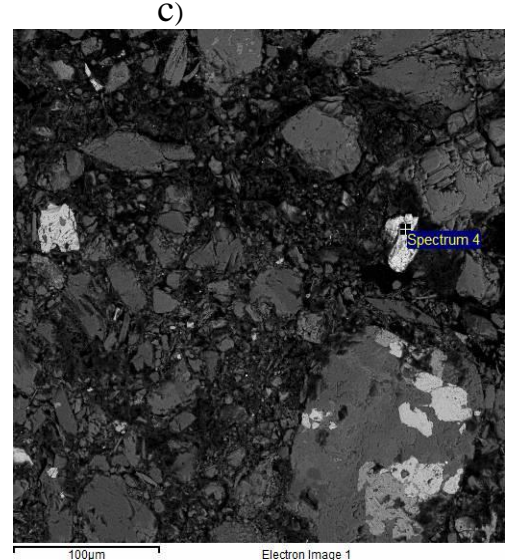

e)

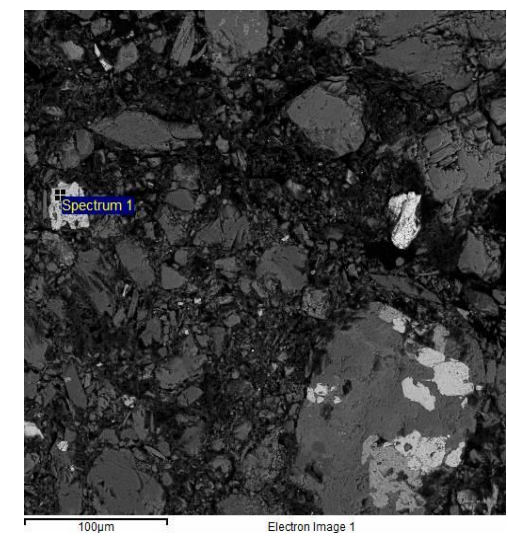

b)

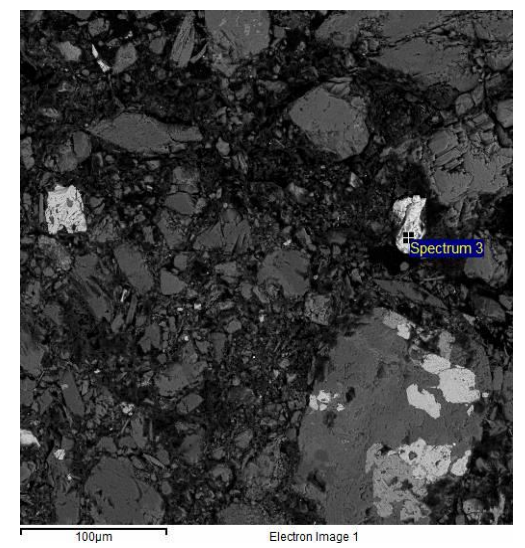

d)

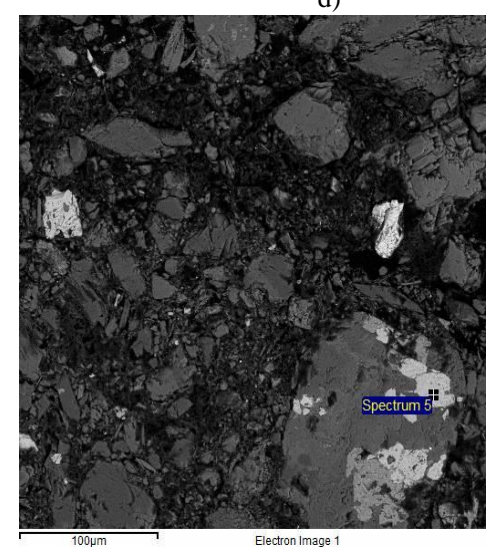

f)

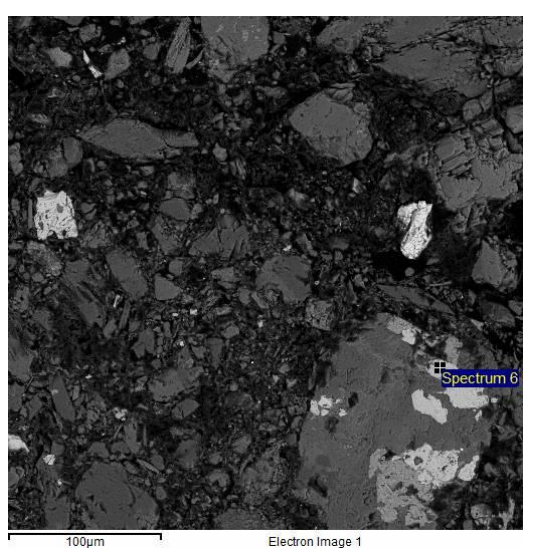

g)

Fig. 5. a) Single massive to partly cataclized aggregate of chalcopyrite $[($ magnif. $\times 200$, crossed nichols (polarizied optical microscope)]; b-c-d-e-f-g) SEM analyses points 


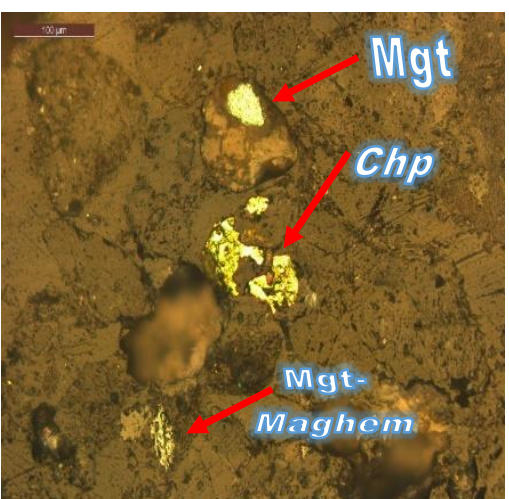

a)

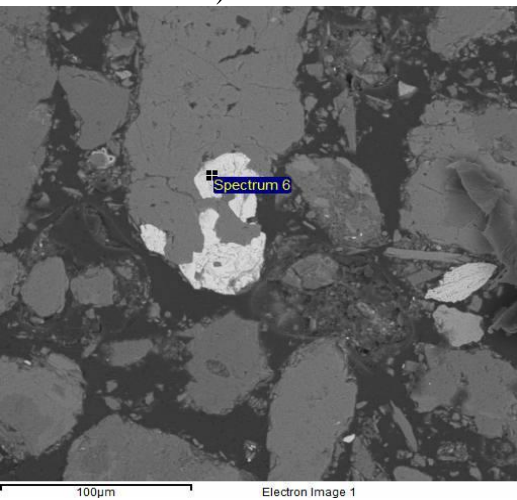

d)

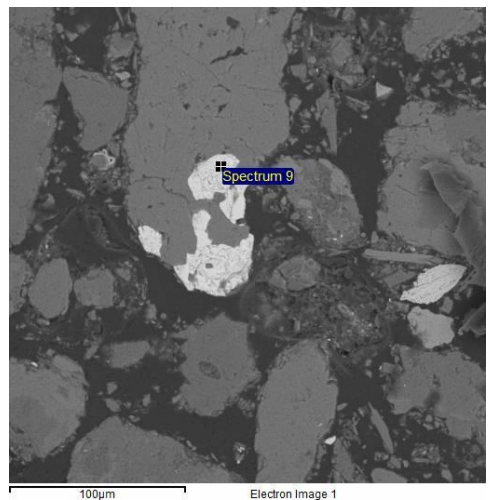

g)

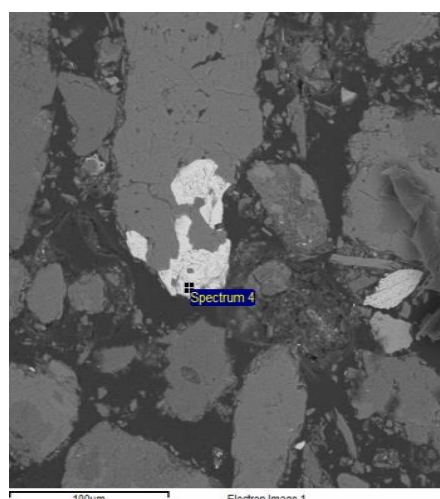

b)

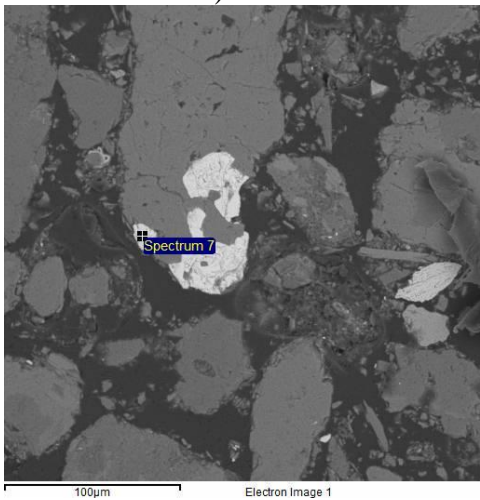

e)

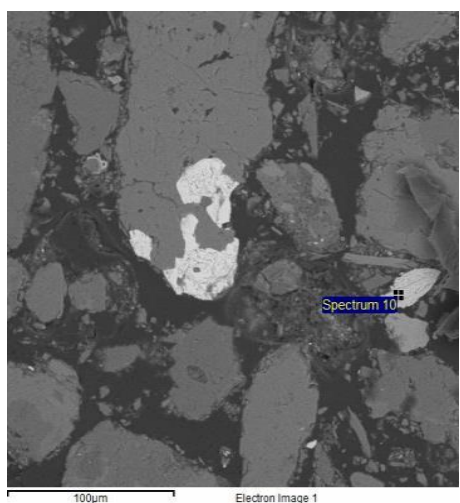

h)

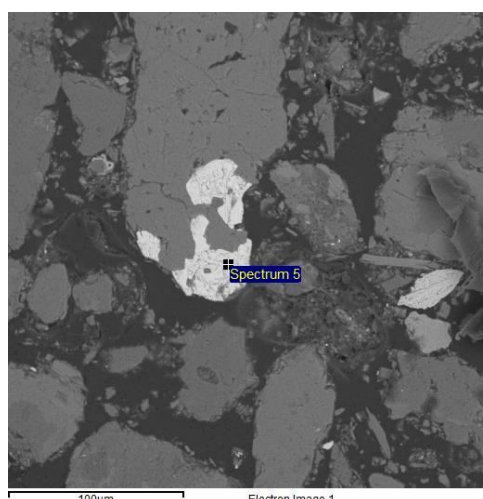

c)

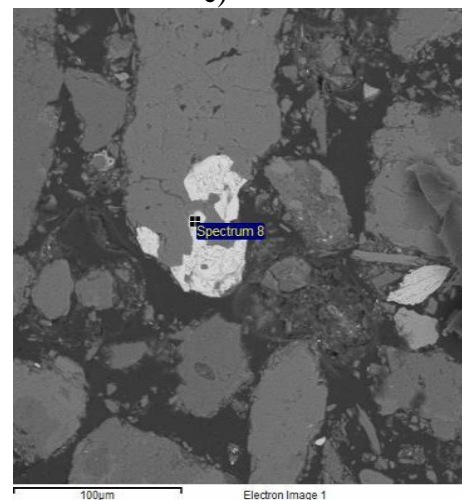

f)

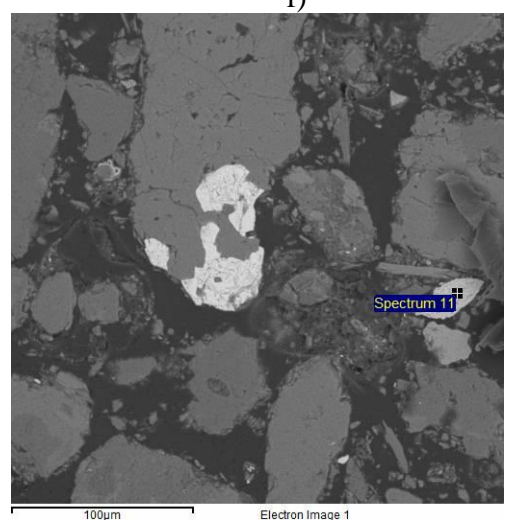

i)

Fig. 6. a) Illustration of several cataclized and intensively corroded chalcopyrite grains in vicinity of magnetite and maghemite magnetite grains [magnif. $\times 200$, crossed nichols (polarized optical microscope)]; b-c-d-e-f-g-h-i) SEM analyses points

Table 3

SEM analysis results of chalcopyrite and magnetite from the Bučim tailing dam (\%wt)

\begin{tabular}{|c|c|c|c|c|c|c|c|c|c|c|c|c|c|}
\hline \multirow{2}{*}{ Spectrum } & \multicolumn{12}{|c|}{$\mathrm{E} 1 \mathrm{e} \mathrm{m}$ e $\mathrm{n} \mathrm{t} \mathrm{s}$} & \multirow{2}{*}{ Total } \\
\hline & S & $\mathrm{Fe}$ & $\mathrm{Cu}$ & $\mathrm{O}$ & $\mathrm{Mn}$ & $\mathrm{Zn}$ & $\mathrm{Ni}$ & $\mathrm{Ag}$ & Co & $\mathrm{Ti}$ & V & $\mathrm{Cr}$ & \\
\hline 1 & - & 68.90 & - & 27.00 & 1.80 & - & - & - & - & 0.50 & 0.90 & 0.90 & 100.00 \\
\hline 2 & - & 70.52 & - & 25.28 & 1.50 & - & - & - & - & 0.60 & 1.10 & 1.00 & 100.00 \\
\hline 3 & 35.22 & 29.11 & 33.30 & - & 0.50 & 1.05 & 0.30 & 0.22 & 0.30 & - & - & - & 100.00 \\
\hline 4 & 36.12 & 29.20 & 32.43 & - & 0.45 & 0.85 & 0.50 & 0.25 & 0.20 & - & - & - & 100.00 \\
\hline 5 & - & 68.90 & - & 26.55 & 2.10 & - & - & - & - & 0.45 & 1.20 & 0.80 & 100.00 \\
\hline 6 & - & 69.19 & - & 26.56 & 2.00 & - & - & - & - & 0.50 & 0.90 & 0.85 & 100.00 \\
\hline
\end{tabular}


Ta b le 4

SEM analysis results of chalcopyrite and magnetite from the Bučim tailing dam (\%wt)

\begin{tabular}{|c|c|c|c|c|c|c|c|c|c|c|c|c|c|}
\hline \multirow{2}{*}{ Spectrum } & \multicolumn{12}{|c|}{$\mathrm{E} 1 \mathrm{e} \mathrm{m}$ e $\mathrm{n}$ t $\mathrm{s}$} & \multirow{2}{*}{ Total } \\
\hline & $\mathrm{S}$ & $\mathrm{Fe}$ & $\mathrm{Cu}$ & $\mathrm{O}$ & $\mathrm{Mn}$ & $\mathrm{Zn}$ & $\mathrm{Ni}$ & $\mathrm{Ag}$ & $\mathrm{Co}$ & $\mathrm{Ti}$ & $\mathrm{V}$ & $\mathrm{Cr}$ & \\
\hline 4 & 34.60 & 29.65 & 32.95 & - & 0.90 & 1.05 & 0.50 & 0.15 & 0.20 & - & - & - & 100 \\
\hline 5 & 34.61 & 29.72 & 32.95 & - & 0.65 & 1.15 & 0.45 & 0.22 & 0.25 & - & - & - & 100 \\
\hline 6 & 33.44 & 30.91 & 33.02 & - & 0.85 & 0.85 & 0.55 & 0.20 & 0.18 & - & - & - & 100 \\
\hline 7 & 34.62 & 29.74 & 33.54 & - & 0.60 & 0.80 & 0.25 & 0.25 & 0.20 & - & - & - & 100 \\
\hline 8 & 34.34 & 29.12 & 33.74 & - & 0.90 & 1.05 & 0.45 & 0.15 & 0.25 & - & - & - & 100 \\
\hline 9 & 34.90 & 28.71 & 33.81 & - & 0.75 & 0.90 & 0.50 & 0.21 & 0.22 & - & - & - & 100 \\
\hline 10 & - & 69.75 & - & 27.40 & - & - & - & - & - & 0.85 & 1.20 & 0.80 & 100 \\
\hline 11 & - & 66.71 & - & 29.94 & - & - & - & - & - & 1.10 & 1.25 & 1.00 & 100 \\
\hline
\end{tabular}

Rare native gold grains, freestanding or occasionally associated with chalcopyrite, determined during our SEM study showed the following com-

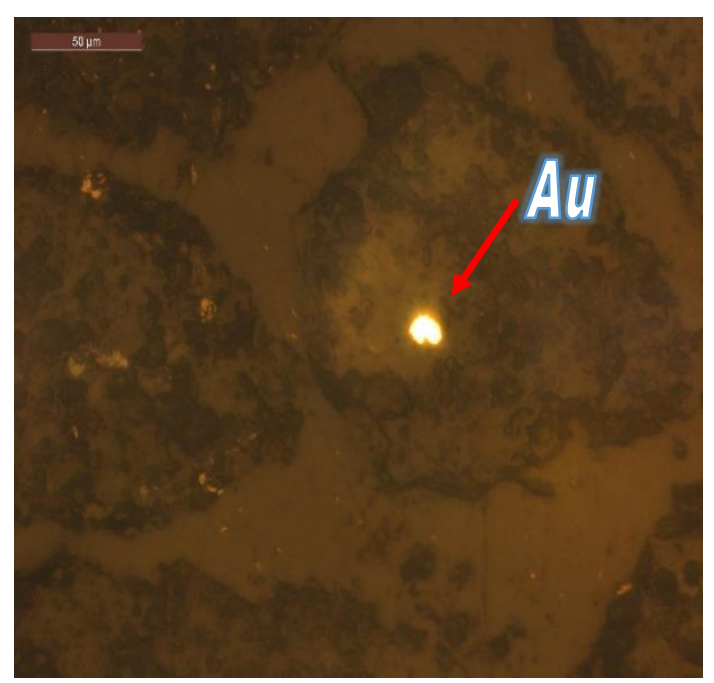

a)

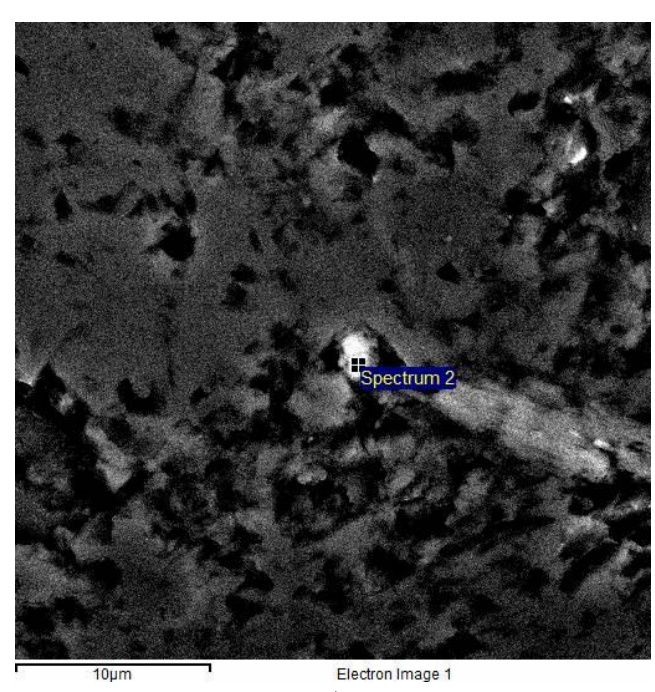

c) position ranges: $98.73-98.79 \% \mathrm{Au}$, as well as with some admixtures of copper $0.65-0.80 \% \mathrm{Cu}$ and tellurium up to $0.22 \%$ Te (Table 5; Figure 7).

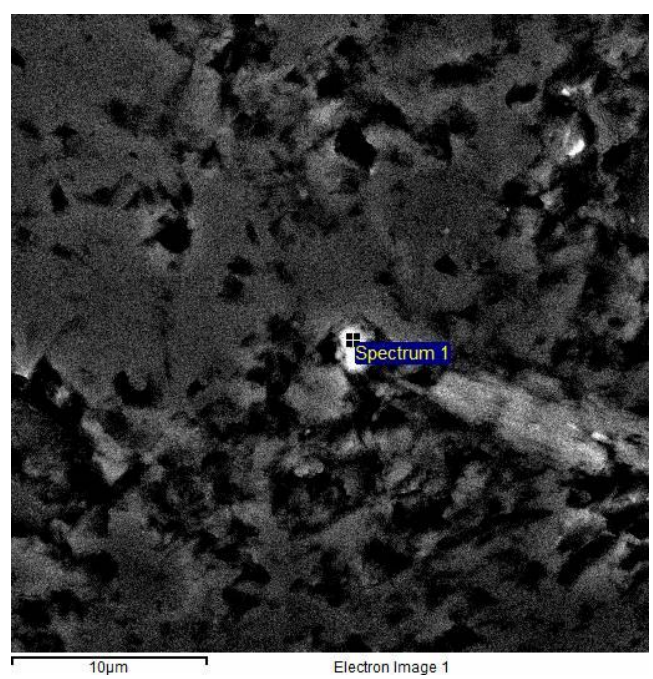

b)

Fig. 7. a) Single twinned gold grain, very massive [magnif. $\times 400$, crossed nichols (polarized optical microsope)]; b-c) SEM analyses points 
Ta ble 5

SEM analysis results of native gold from the Bučim tailing dam (\%wt)

\begin{tabular}{ccccccc}
\hline \hline \multirow{2}{*}{ Spectrum } & \multicolumn{3}{c}{ E 1 e m e $\mathrm{n} \mathrm{t}$ s } & \multirow{2}{*}{ Total } \\
& $\mathrm{Au}$ & $\mathrm{Ag}$ & $\mathrm{Cu}$ & $\mathrm{Te}$ & \\
\hline 1 & 98.73 & 0.25 & 0.80 & 0.22 & 100.00 \\
2 & 98.79 & 0.38 & 0.65 & 0.18 & 100.00 \\
\hline \hline
\end{tabular}

Native gold composition determined within this study complies well with some other similar facilities around the World (Fu et al., 2018), as well as findings for the primary Bučim ore deposit (Čifliganec, 1986, 1993; Serafimovski et al.).

Table 6

\begin{tabular}{|c|c|c|c|c|c|c|c|c|}
\hline \multirow{2}{*}{ Spectrum } & \multicolumn{7}{|c|}{$\mathrm{E} 1 \mathrm{e} \mathrm{m}$ e $\mathrm{n} \mathrm{t} \mathrm{s}$} & \multirow{2}{*}{ Total } \\
\hline & $\mathrm{S}$ & $\mathrm{Fe}$ & $\mathrm{Cu}$ & $\mathrm{Ag}$ & V & $\mathrm{Mn}$ & $\mathrm{Ni}$ & \\
\hline 1 & 51.94 & 45.01 & 1.1 & 0.15 & 0.5 & 1.15 & 0.15 & 100 \\
\hline 2 & 53.66 & 44.04 & 0.8 & 0.22 & - & 1.01 & 0.27 & 100 \\
\hline 3 & 52.59 & 44.57 & 0.92 & 0.17 & 0.35 & 1.2 & 0.2 & 100 \\
\hline
\end{tabular}

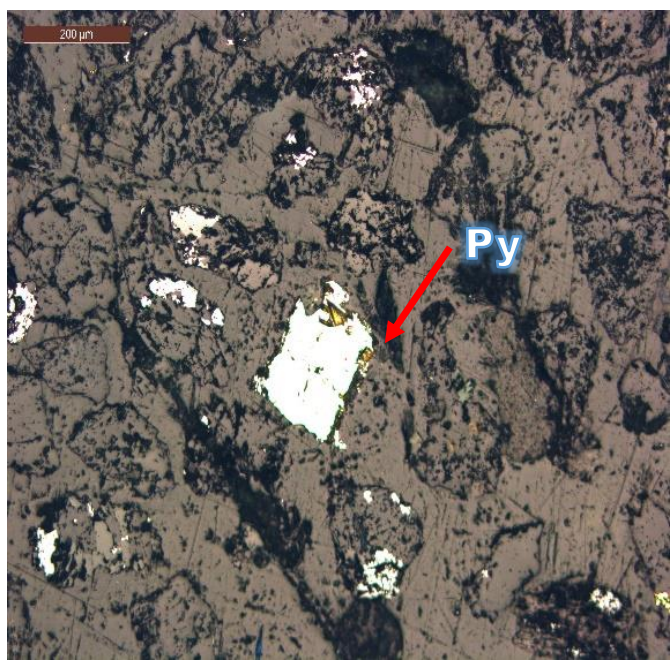

a)

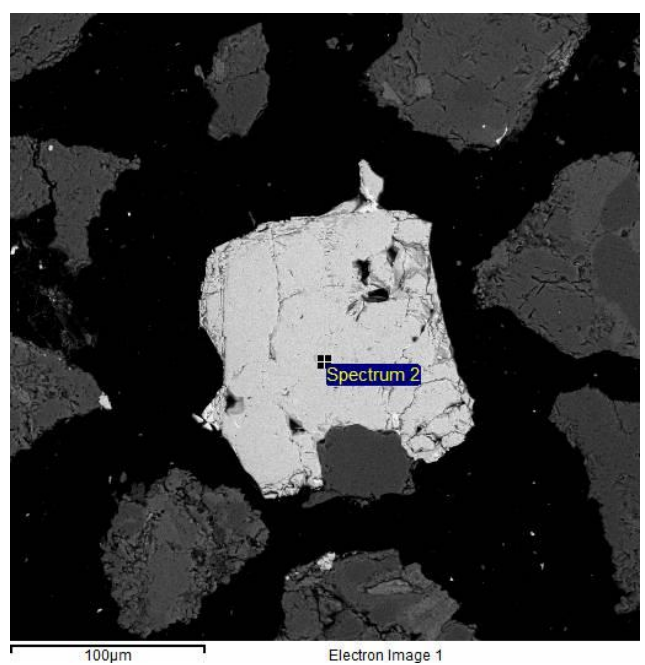

c)

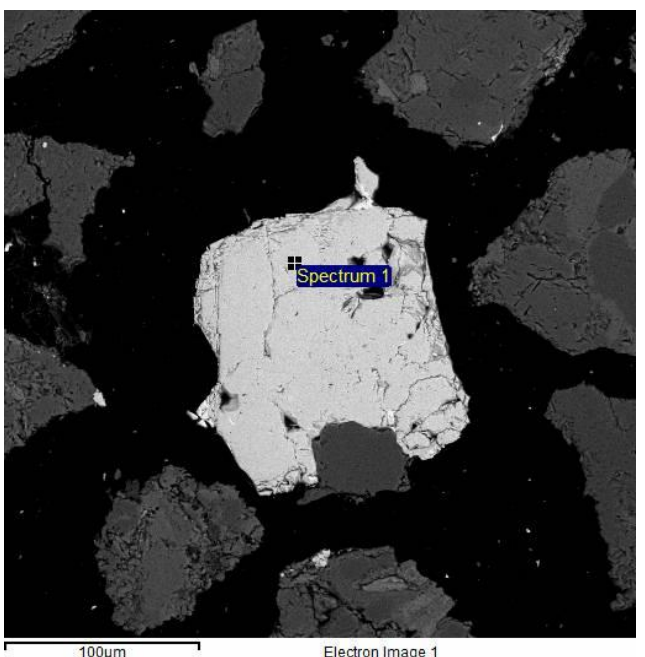

b)

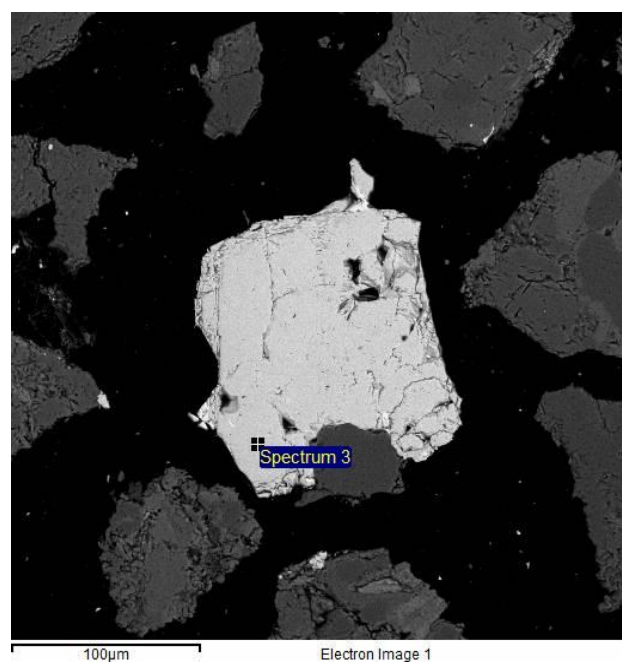

d)

Fig. 8. a) Large, massive and idioimorphic pyrite crystal, partly cataclized and corroded [(magnif. $\times 100$, crossed nichols (polarazing optical microscope)]; b-c-d) SEM analyses points 
Table 7

SEM analysis results of chalcopyrite from the Bučim tailing dam (\%wt)

\begin{tabular}{cccccccccc}
\hline \multirow{2}{*}{ Spectrum } & \multicolumn{10}{c}{$\mathrm{E} \mathrm{l}$ e $\mathrm{m} \mathrm{e} \mathrm{n} \mathrm{t}$} & $\mathrm{Cu}$ & Total \\
& $\mathrm{S}$ & $\mathrm{Fe}$ & $\mathrm{Cu}$ & $\mathrm{Mn}$ & $\mathrm{Zn}$ & $\mathrm{Ni}$ & $\mathrm{Ag}$ & $\mathrm{Co}$ & \\
\hline 1 & 34.89 & 29.4 & 32.51 & 0.8 & 1.15 & 0.75 & 0.15 & 0.35 & 100 \\
2 & 33.71 & 30.21 & 34.53 & - & 0.85 & 0.5 & 0.2 & - & 100 \\
3 & 34.93 & 29.94 & 32.95 & 0.5 & 1 & - & 0.18 & 0.5 & 100 \\
4 & 33.94 & 29.6 & 33.59 & 0.65 & 0.9 & 0.8 & 0.22 & 0.3 & 100 \\
\hline \hline
\end{tabular}

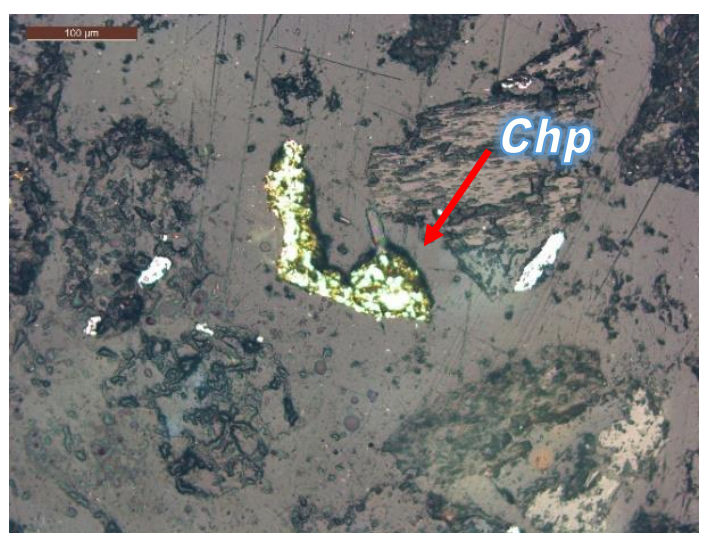

a)

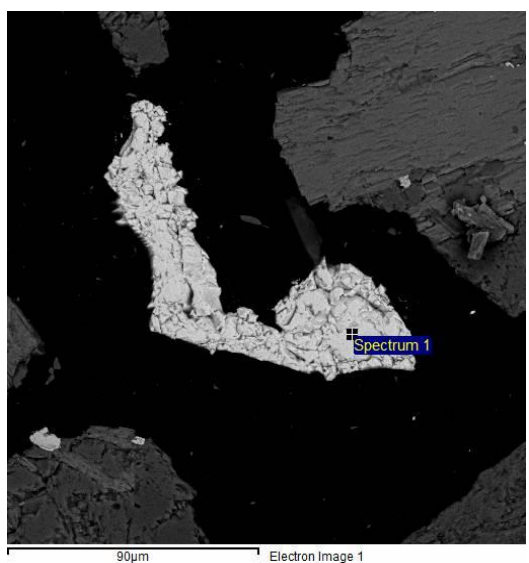

b)

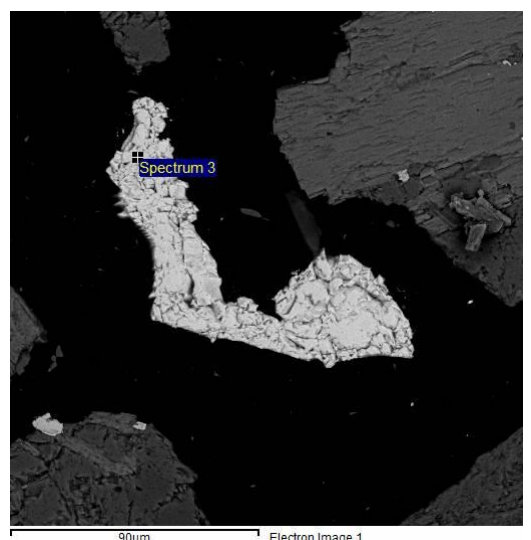

d)

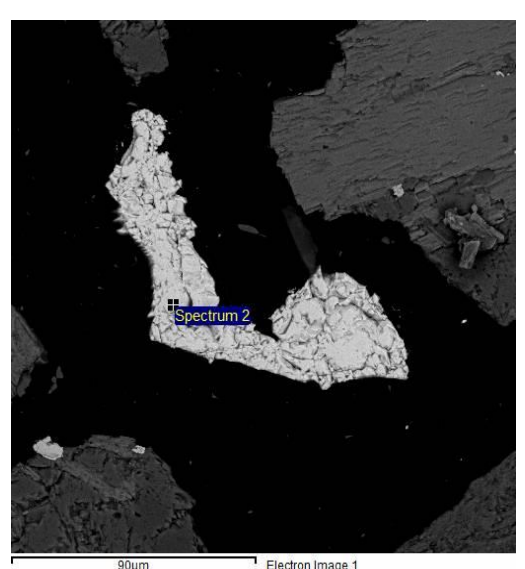

c)

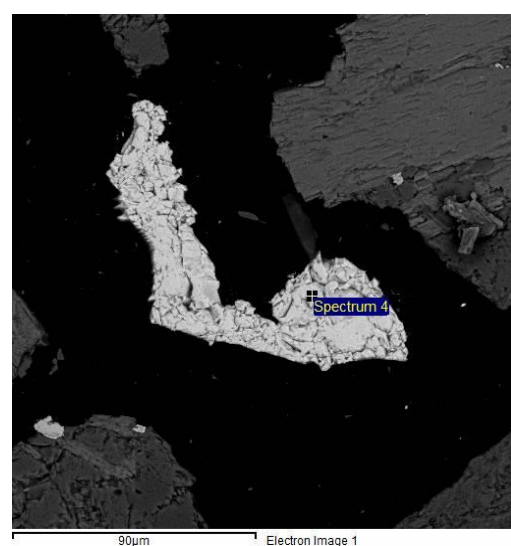

e)

Fig. 9. a) Large, massive and idiomorphic chalcopyrite crystal, partly cataclized and corroded [magnif. $\times 200$, crossed nichols (polarized optical microscope)]; b-c-d-e) SEM analyses points 


\section{QUANTITATIVE ANALYSIS RESULTS}

According to the project proposal activities within the mineralogical analysis of the material from the Bučim hydrotailing dam a quantification was foreseen, which we realized on a number of selected samples. In order to cover evenly all parts of the research area of the Bučim hydrotailing dam we decided to take one trial from each drill hole $(6$ in total), but from different levels in all 6 drill holes, with a certain equilibrium representation at all depths, and however, to meet the optimum quantification minimum. For these needs, a total of 6 samples from the following levels were taken:

- B1 from $24 \mathrm{~m}$ to $26 \mathrm{~m}$

- B2 from $58 \mathrm{~m}$ to $60 \mathrm{~m}$

- B3 from $26 \mathrm{~m}$ to $28 \mathrm{~m}$

- B4 from $30 \mathrm{~m}$ to $32 \mathrm{~m}$

- B5 from $52 \mathrm{~m}$ to $54 \mathrm{~m}$

- B6 from $30 \mathrm{~m}$ to $32 \mathrm{~m}$

From selected materials were prepared polished sections where an optical microscope determined the presence of ore minerals from the Bučim ore paragenesis, where had been determined presence of pyrite, chalcopyrite, magnetite and some less abundant mineral phases.

Then the samples with the required amount of material were sent for quantitative analysis to the laboratories of the Faculty of Natural Sciences and Engineering at the University of Ljubljana. Even before the samples have been analyzed, we have been told by the XRD operators' that the quantification of the material will be done within the sensitivity of the method, i.e., the determination of those mineral phases whose total participation in the analyzed material is below $1 \%$ will be aggravated (Table 8 )

From the enclosed results (Table 8), it could be seen that the reliability of the provision was in favor of the petrogenic minerals (unprocessed minerals), which was a great opportunity for us as we had no other treatment for them, while the ore minerals were found in contents below $1 \%$ and their quantification cannot reliably confirm their intensity (Figure 10).

However, the quantification of ore minerals is also present in the paper through the mineralogical (ore microscopy and scanning electron microscopy) analysis of tailings.

Table 8

Quantitative XRD mineralogical analysis of samples from the Bučim hydrotailing dam (in \%wt)

\begin{tabular}{ccccccccccccc}
\hline \hline Dataset name & Quartz & Orthoclase & \multicolumn{1}{c}{ Andesine } & Actinolite & Biotite & Kaolinite & Clinochlore & Magnetite & Pyrite & Chalcopyrite & Total \\
\hline $3 \mathrm{~b} 12426$ & 36.00 & 26.70 & 30.80 & 1.10 & 1.70 & 0.00 & 2.60 & 0.70 & 0.00 & 0.20 & 99.80 \\
$11 \mathrm{~b} 25860$ & 37.10 & 24.20 & 26.30 & 0.20 & 2.00 & 1.00 & 7.60 & 1.00 & 0.30 & 0.30 & 100.00 \\
$15 \mathrm{~b} 32628$ & 36.30 & 22.00 & 36.30 & 1.20 & 1.50 & 0.20 & 2.00 & 0.00 & 0.40 & 0.20 & 100.10 \\
$20 \mathrm{~b} 43032$ & 33.00 & 27.60 & 32.60 & 1.40 & 2.10 & 0.60 & 2.30 & 0.00 & 0.40 & 0.10 & 100.10 \\
$26 \mathrm{~b} 55254$ & 34.40 & 27.60 & 30.90 & 1.40 & 2.10 & 0.90 & 2.45 & 0.50 & 0.20 & 0.00 & 100.45 \\
$29 \mathrm{~b} 63032$ & 38.20 & 27.50 & 29.90 & 0.00 & 1.70 & 0.20 & 2.10 & 0.20 & 0.10 & 0.00 & 99.90 \\
\hline \hline
\end{tabular}

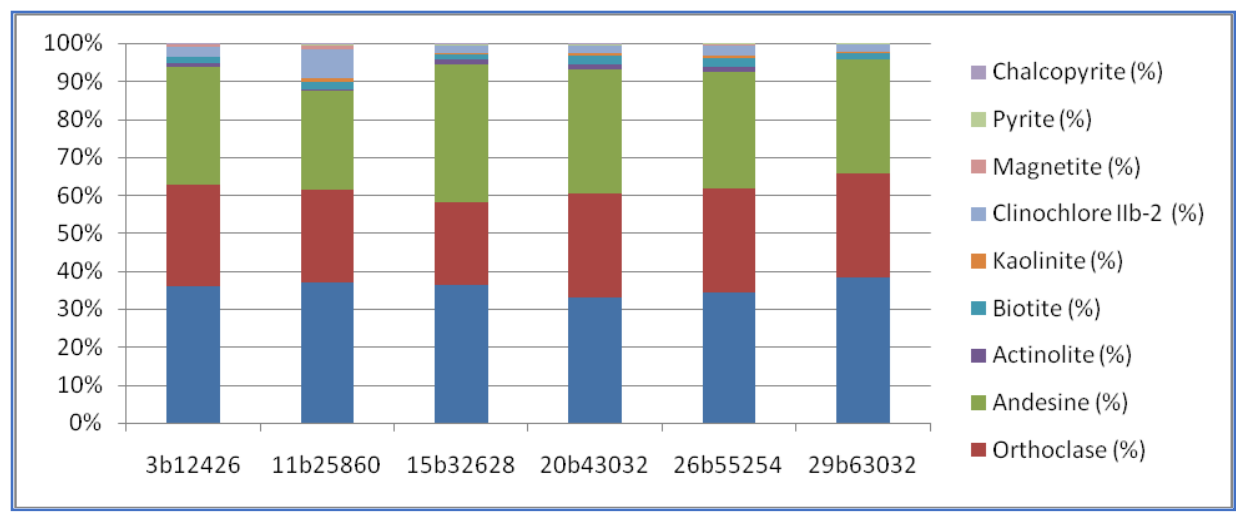

Fig. 10. Frequency graph of major minerals in samples from the Bučim hydrotailing dam (XRD analysis) 


\section{CONCLUSION}

The tailing dam in the Bučim mine is a significant technogenic potential of useful raw materials, primarily copper, gold, silver and associated rare and dispersed elements that are deposited in the period from 1979 to 2020 as a result of active exploitation of porphyry copper ores from the Bučim mine. Over $135 \mathrm{Mt}$ of deposited flotation tailings is a challenge not only for mineralogical examinations but also for detailed examinations aimed at valorizing the useful components. The performed drilling of the tailings and the conducted mineralogical analysis confirmed that within the tailings, in addition to the disseminated mineralization, there are elongated-lens forms of concentration of mineral compo- nents at certain levels in the vertical pillar of the deposited material. The most common ore mineral is chalcopyrite which shows a constant composition with small variations, which do not deviate much from its theoretical composition, while native gold shows a high degree of purity with its characteristic impurities, silver, copper and tellurium. Pyrites and magnetites are quantitatively quite present, which coincides with their presence in the primary ores of the Bučim mine. The conducted mineralogical analysis opens an initiative for further detailed geochemical examination of the tailings material with the possibility of valorization of the useful components of this technogenic deposit.

\section{REFERENCES}

Čifliganec, V. (1986): Forms of gold appearance in the porphyry deposit [In Serbian], XI Congress of Yugoslavian Geologists, Tara, Book 4, pp 181-191.

Čifliganec, V. (1993): Copper Mineralization in the Republic of Macedonia: Types and Distribution Patterns [In Macedonian with extended summary in English]. "Ss. Cyril and Methodius" University - Skopje, Faculty of Mining and Geology - Štip, Spec. Issue 1, 303 pp.

Čifliganec, V., Serafimovski, T. \& Stefanova, V. (1997): Content and distribution of gold-bearing minerals from the Bučim porphyry copper deposit. Symposium - Annual Meeting, Dojran, Proceedings, Abstract, 1, 277-278.

Deer, W. A., Howie, R. A. and Zussman, J. (1962): Rock-forming Minerals, Vol. 5, Non-Silicates, 56-88.

Fu, P., Li, Z., Feng, J. and Bian, Z. (2018): Recovery of gold and iron from cyanide tailings with a combined direct reduction roasting and leaching process. Metals 8 (7), 561, pp 1-13, DOI:10.3390/met8070561

Kogan, B. S. and Solovev, V. A. (1993): Technological-Geochemical Evaluation of Reserves of Precious Metals within the Bučim Mine Ttailing Dam [in Russian], Institute for Mineralogy, Geochemistry and Crystalochemistry of Rare Elements (IMGRE) - Moscow, Russia, 96 pp.

Lottermoser, B. G. (2007): Mine Wastes: Characterization, Treatment and Environmental Impacts. School of Earth and Environmental Sciences, James Cook University, Australia, 304 pp.

Okrusch M. and Matthes S. (2005): Mineralogie - Eine Einführung in die spezielle Mineralogie, Petrologie und Lagerstättenkunde; Springer-Verlag, 38 pp,; ISBN: 3540238123

Palache, C., Berman, H. and Frondel, C. (1944). Dana's System of Mineralogy ( $7^{\text {th }}$ edition), Vol. I, 282-290.

Pavičević, M., Rakić, S., Gržetić, I. and Golijanin, D. (1982): Study of occurence of gold, silver and other accessory and rare elements in ores from the central ore body Bučim. [In Serbian], Ulema, Belgrade, 164 pp.

Ristović, I. (2020): Study of historical data on Cu-tailings in Bor mining complex - Serbia. Deliverable for the zero waste recovery of copper tailings in the ESEE region (RISCuRE), 13 pp.

Robb, L. (2005): Introduction to Ore-forming Processes. Willey-Blackwell Publishing, Oxford. $382 \mathrm{pp}$

Serafimovski, T., Čifliganec, V., Mankov, S. (1993): Forma na prisustvoto na zlato vo porfirskoto bakarno naoǵalište Bučim (Istočna Makedonija). XXIV Oktobarsko savetovanje rudara i metalurga, p. 52-55, Bor.

Serafimovski, T., Tasev, G. and Stafilov, T. (2020): The content of copper and heavy metals in the multilayer soil mud from the Bučim Lake under the Bučim mine's waste dump, Republic North Macedonia. Tehnika, 3 (1). pp. 297-304. ISSN 0040-2176.

Serafimovski, T., Ristović, I., Boev, B., Tasev, G., Boev, I., Serafimovski, D. and Dolenec, M. (2021a): Mineralogical analysis of samples from the old Bor mine flotation tailing, Republic Serbia. Natural Resources and Technologies, 15 (1), pp. 37-50. ISSN 1857-6966.

Serafimovski, T., Ristović, I., Boev, B., Tasev, G., Boev, I., Serafimovski, D. and Dolenec, M., (2021b): Some geochemical and mineralogical features of samples from old Bor's tailing dam. Geologica Macedonica, Special Issue No. 5 (5), pp. 157-164.

Serafimovski, T., Dolenec, T., Tasev, G., Serafimovski, D., Rogan Šmuc, N. and Dolenec, M. (2021c): Au-Pd and BiSe bearing pyrite and chalcopyrite from the Bučim copper mine, Eastern Macedonia. Materials and Technology, $\mathbf{5 5}$ (1), pp. 71-76, ISSN 1580-2949.

Tudjarov, N., Mitevski, G., Zdravkovski, T. (1996): Technogenic Deposits. 191-197. 


\title{
Р е 3 и м е
}

\section{МИНЕРАЛОШКА АНАЛИЗА НА ПРИМЕРОЦИ ОД ДУПЧЕТИНИ ВО ХИДРОЈАЛОВИШТЕТО НА БУЧИМ}

\author{
Тодор Серафимовски ${ }^{1}$, Блажо Боев ${ }^{1}$, Горан Тасев ${ }^{1}$, Иван Боев $^{1}$, Далибор Серафимовски ${ }^{2}$

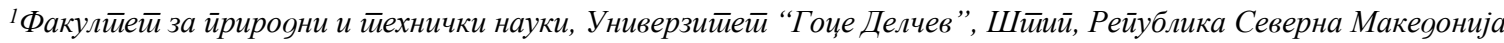

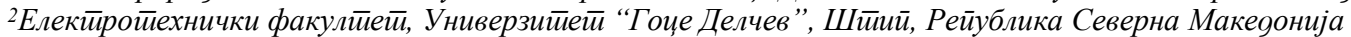

Клучни зборови: рудник за бакар Бучим; хидројаловина; рудна микроскопија; минерална асоцијација; примероци

\begin{abstract}
Хидројаловиштето на рудникот Бучим претставува важен сегмент во експлоатацијата на порфирските руди од рудникот и во периодот од 40 години во него е депонирано преку $135 \mathrm{Mt}$ јаловина, во која има интересни содржини на злато, бакар, сребро и други ретки и расеани елементи, што воедно јаловиштето го прави техногено наоѓалиште. Во рамките на овој труд е третиран минералошкиот аспект на јаловината врз база на проби земени од 6 дупчетини и 30 изработени рудно-микроскопски препарати. Со деталниот микроскопски преглед е потврдена очекувана минерална асоцијација претставена со Fе-оксиди, главно магнетит и магхемит, потоа халкопирит, самородно злато, пирит, сулфосоли и др. Испитувањата со скенирачки електронски ми-
\end{abstract}

кроскоп ја потврдија констатираната минерална асоцијација и ги дадоа составите на главните рудни минерали. При анализата и споредбата со стандардите за вакви типови минерални видови е констатирано дека станува збор за водечки минерали, во прв ред халкопирит и самородно злато, кои покажуваат висок степен на чистота, кај кои варијациите на бакарот се движат од 32.43 до $34.53 \%$ Сu кај халкопиритот и од 98.73 до $98.79 \%$ Au кај самородното злато. Малите варијации особено кај самородното злато се должат на присуството на $\mathrm{Ag}, \mathrm{Cu}$ и Те. Вакви слични односи се констатирании и кај другите испитувани минерални видови под скенирачкиот електронски микроскоп, што може да се види од презентираните податоци во рамките на трудот 
